Article

\title{
Emerging Fusarium Mycotoxins Fusaproliferin, Beauvericin, Enniatins, and Moniliformin in Serbian Maize
}

\author{
Igor Jajić $^{1}$, Tatjana Dudaš ${ }^{1, *}$, Saša Krstović ${ }^{1}{ }^{(0)}$, Rudolf Krska ${ }^{2,3}{ }^{\circledR}$, Michael Sulyok ${ }^{2}{ }^{\circledR}$, \\ Ferenc Bagi ${ }^{1}$, Zagorka Savić ${ }^{1}$, Darko Guljaš ${ }^{1}$ and Aleksandra Stankov ${ }^{1}$ \\ 1 Faculty of Agriculture, University of Novi Sad, 21000 Novi Sad, Serbia; igor.jajic@stocarstvo.edu.rs (I.J.); \\ sasa.krstovic@stocarstvo.edu.rs (S.K.); bagifer@polj.uns.ac.rs (F.B.); zagorka.savic@polj.uns.ac.rs (Z.S.); \\ darko.guljas@stocarstvo.edu.rs (D.G.); aleksandra.stankov@polj.uns.ac.rs (A.S.) \\ 2 Institute of Bioanalytics and Agro-Metabolomics, Department IFA-Tulln, University of Natural Resources \\ and Life Sciences Vienna (BOKU), A-3430 Tulln, Austria; rudolf.krska@boku.ac.at (R.K.); \\ michael.sulyok@boku.ac.at (M.S.) \\ 3 Institute for Global Food Security, School of Biological Sciences, Queens University Belfast, University Road, \\ Belfast BT7 1NN, UK \\ * $\quad$ Correspondence: tatjana.dudas@polj.uns.ac.rs; Tel.: +381-655-237-432-54
}

Received: 30 March 2019; Accepted: 17 June 2019; Published: 19 June 2019

\begin{abstract}
Emerging mycotoxins such as moniliformin (MON), enniatins (ENs), beauvericin (BEA), and fusaproliferin (FUS) may contaminate maize and negatively influence the yield and quality of grain. The aim of this study was to determine the content of emerging Fusarium mycotoxins in Serbian maize from the 2016, 2017, and 2018 harvests. A total of 190 samples from commercial maize production operations in Serbia were analyzed for the presence of MON, ENs, BEA, and FUS using liquid chromatography-tandem mass spectrometry (LC-MS/MS). The obtained results were interpreted together with weather data from each year. MON, BEA, and FUS were major contaminants, while other emerging mycotoxins were not detected or were found in fewer samples $(<20 \%)$. Overall contamination was highest in 2016 when MON and BEA were found in $50-80 \%$ of samples. In 2017 and 2018, high levels of MON, FUS, and BEA were detected in regions with high precipitation and warm weather during the silking phase of maize (July and the beginning of August), when the plants are most susceptible to Fusarium infections. Since environmental conditions in Serbia are favorable for the occurrence of mycotoxigenic fungi, monitoring Fusarium toxins is essential for the production of safe food and feed.
\end{abstract}

Keywords: emerging mycotoxins; Fusarium; LC-MS/MS; maize; Serbia

Key Contribution: Up to present, little effort has been put forth in terms of quality control regarding emerging mycotoxins in Serbian maize. This article gives the first insight into the current situation of emerging mycotoxin contaminations in Serbian maize and recommends further monitoring studies necessary for legislative purposes since climate conditions are favorable for the development of mycotoxin-producing fungi that pose a threat to food and food quality.

\section{Introduction}

Mycotoxins have become one of the most important food contaminants in modern society. They are toxic secondary metabolites that are usually produced by Aspergillus, Penicillium, and Fusarium fungi in favorable environmental conditions. Among these species, Fusarium are the most prevalent mycotoxin-producing fungi in the northern temperate regions, and mainly Central and 
SoutheasternEurope [1]. Fusarium molds are known as producers of several mycotoxins, including both "traditional" as trichothecenes, zearalenone, and the fumonisins [2] and "emerging toxins" as moniliformin (MON), enniatins (ENs), beauvericin (BEA), and fusaproliferin (FUS) [3]. Additionally, Kovalsky et al. [3] found a co-occurrence of "traditional" toxins with EN, MON, and BEA. The main producers of emerging Fusarium mycotoxins in cereals are Fusarium avenacum, Fusarium verticillioides (moniliforme), Fusarium proliferatum, and Fusarium subglutinans [1].

MON is a sodium or potassium salt of 1-hydroxycyclobut-1-ene-3,4-dione [4]. It was discovered by Cole et al. [5] while screening for toxigenic products of $F$. verticillioides isolated from southern leaf blight-damaged maize seed. BEA and ENs belong to a group of cyclodepsipeptidesthat may have antibiotic, insecticidal, and cytotoxic effects [6-9]. FUS is a toxic sesterterpene originally isolated by Ritieni et al. [10] from F. proliferatum in autoclaved maize cultures.

BEA is known as a cholesterol acyltransferase inhibitor [11] and it is toxic to several human cell lines [12,13]. Additionally, BEA can induce apoptosis and DNA fragmentation [14]. FUS is a sesterterpene identified from maize cultures of $F$. proliferatum isolated from maize [15]. FUS is toxic to Artemiasalina, to the lepidopteran cell line SF-9 and to the human nonneoplastic B-lymphocyte cell line IARC/LCL 171 [16]. FUS can induce teratogenic effects in chicken embryos [17]. Kriek et al. [18] found that ducklings and rats fed diets containing MON led to muscular weakness, respiratory distress, cyanosis, coma, and death.

There is limited data on the toxicity and occurrence of "emerging" mycotoxins. These mycotoxins are neither routinely determined nor legislatively regulated. Their presence has been reported in cereals from several countries [19-23]. In a recent EFSA report [24], an opinion on the presence of ENNs and BEA in food and feed was made, but the lack of relevant toxicity data did not a risk assessment. Currently, maximum levels for emerging Fusarium mycotoxins are not been regulated.

Maize is one of the most susceptible cereals to the presence of Fusarium molds. Infection of maize may lead to grain size and protein decreasing as well as harming germination. The final result is a decrease in yield and feed quality. Additionally, a consequential mycotoxin production is another highly problematic outcome of Fusarium infection.

In Serbia, arable land covers approximately $75.5 \%$ of utilized agricultural land. In the structure of sown arable land areas, cereals comprised $67.9 \%$, industrial crops comprised $15.7 \%$, vegetables comprised $2.6 \%$, and fodder crops comprised $9.1 \%$ in 2016 [25]. However, cereals were grown on 1,763,575 ha in 2016, which is lower compared to 2015 (1,782,010 ha), and 2014 (1,819,188 ha). In 2016, maize was harvested from 1,010,097 ha, with a total production of 73,767,371 t. The average yield in 2016 was $7.3 \mathrm{t} / \mathrm{ha}$, which was higher than in 2015 (5.4 t/ha), and slightly lower in comparison with 2014 (7.5 t/ha) [25]. When compared to 2016, the total production of maize decreased by $45.5 \%$ in 2017, while the average yield was only $4.0 \mathrm{t} / \mathrm{ha}$ [26]. In 2018, expected production of maize was 6,965,000 $\mathrm{t}$, which was $73.3 \%$ higher than in 2017, with an average yield ofapproximately $7.6 \mathrm{t} / \mathrm{ha}$ [27]. High maize production in 2018 positioned Serbia among the top ten maize exporters [28] and among the top twenty maize producers in the world [29].

In considering these facts, the aim of this study was to determine the current state of the level of emerging Fusarium mycotoxins in Serbian maize. Additionally, an effort was made to relate the obtained results with the weather conditions recorded during the trial period.

\section{Results}

\subsection{Occurrence of Emerging Toxins in Maize Samples}

Maize samples collected during the 2016 harvest were analyzed and the results are shown in Table 1 . MON and BEA had the highest presence among emerging mycotoxins ( $>80 \%)$, except in the West-Backa region (50\%). Other emerging mycotoxins were not detected at all or were found in fewer samples $(<20 \%)$. Overall, maize samples from the Middle-Banat region were the most contaminatedfor all investigated emerging mycotoxins. MON, BEA, and FUS were present in all regions. Mean levels 
of MON ranged from $189.97 \mu \mathrm{g} / \mathrm{kg}$ (West-Backa) to $920.10 \mu \mathrm{g} / \mathrm{kg}$ (Srem). BEA mean levels were between $6.82 \mu \mathrm{g} / \mathrm{kg}$ (West-Backa) and $34.79 \mu \mathrm{g} / \mathrm{kg}$ (Srem). FUS levels were the highest among all tested mycotoxins. They ranged from $328.50 \mu \mathrm{g} / \mathrm{kg}$ in South-Backa to $12,272.00 \mu \mathrm{g} / \mathrm{kg}$ in a sample from the West-Backa region. ENs were found in all regions except Srem, with the highest mean levels in samples originating from Middle-Banat.

Table 1. Occurrence of emerging toxins in maize samples collected in the Republic of Serbia in 2016.

\begin{tabular}{|c|c|c|c|c|c|c|c|}
\hline & MON & BEA & EN A & EN A1 & EN B & EN B1 & FUS \\
\hline \multicolumn{8}{|c|}{ South-Banat region } \\
\hline Average $\pm \mathrm{SD}(\mu \mathrm{g} / \mathrm{kg})$ & $237 \pm 230$ & $18.7 \pm 30.3$ & - & 0.59 & 7.55 & 4.86 & $328 \pm 268$ \\
\hline Range $(\mu \mathrm{g} / \mathrm{kg})$ & $5.06-850$ & $0.41-129$ & - & - & - & - & $85.4-1121$ \\
\hline Samples & 21 & 21 & 21 & 21 & 21 & 21 & 21 \\
\hline Positive samples (\%) & $21(100.0)$ & $20(95.2)$ & 0 & $1(4.8)$ & $1(4.8)$ & $1(4.8)$ & $16(76.2)$ \\
\hline \multicolumn{8}{|c|}{ South-Backa region } \\
\hline Average $\pm \mathrm{SD}(\mu \mathrm{g} / \mathrm{kg})$ & $534 \pm 410$ & $13.7 \pm 26.7$ & $0.25 \pm 0.19$ & $0.24 \pm 0.18$ & - & - & $827 \pm 1032$ \\
\hline Range $(\mu \mathrm{g} / \mathrm{kg})$ & $15.3-1450$ & $0.10-111$ & $0.12-0.47$ & $0.13-0.44$ & - & - & $91.3-4687$ \\
\hline Samples & 29 & 29 & 29 & 29 & 29 & 29 & 29 \\
\hline Positive samples (\%) & $26(89.7)$ & $26(89.7)$ & $3(10.3)$ & $3(10.3)$ & 0 & 0 & $22(75.9)$ \\
\hline \multicolumn{8}{|c|}{ Middle-Banat region } \\
\hline Average $\pm \mathrm{SD}(\mu \mathrm{g} / \mathrm{kg})$ & $576 \pm 391$ & $7.06 \pm 14.4$ & $8.78 \pm 11.8$ & $9.30 \pm 15.7$ & $0.80 \pm 1.01$ & $8.27 \pm 11.4$ & $1018 \pm 396$ \\
\hline Range $(\mu \mathrm{g} / \mathrm{kg})$ & $7.18-1228$ & $0.23-49.7$ & $0.41-17.1$ & $0.11-27.4$ & $0.08-1.52$ & $0.20-16.3$ & $450-1738$ \\
\hline Samples & 12 & 12 & 12 & 12 & 12 & 12 & 12 \\
\hline Positive samples (\%) & $12(100.0)$ & $11(91.7)$ & $2(16.7)$ & $3(25.0)$ & $2(16.7)$ & $2(16.7)$ & $11(91.7)$ \\
\hline \multicolumn{8}{|c|}{ Srem region } \\
\hline Average $\pm \mathrm{SD}(\mu \mathrm{g} / \mathrm{kg})$ & $920 \pm 1649$ & $34.8 \pm 67.8$ & - & - & - & - & $1736 \pm 2384$ \\
\hline Range $(\mu \mathrm{g} / \mathrm{kg})$ & $3.03-3856$ & $0.27-136$ & - & - & - & - & $312-4488$ \\
\hline Samples & 5 & 5 & 5 & 5 & 5 & 5 & 5 \\
\hline Positive samples (\%) & $5(100.0)$ & $4(80.0)$ & 0 & 0 & 0 & 0 & $3(60.0)$ \\
\hline \multicolumn{8}{|c|}{ West-Backa region } \\
\hline Average \pm SD $(\mu \mathrm{g} / \mathrm{kg})$ & $190 \pm 192$ & $6.82 \pm 9.90$ & 0.49 & 0.53 & - & 0.22 & 12272 \\
\hline Range $(\mu \mathrm{g} / \mathrm{kg})$ & $34.8-405$ & $0.03-18.2$ & - & - & - & - & - \\
\hline Samples & 6 & 6 & 6 & 6 & 6 & 6 & 6 \\
\hline Positive samples (\%) & $3(50.0)$ & $3(50.0)$ & $1(16.7)$ & $1(16.7)$ & 0 & $1(16.7)$ & $1(16.7)$ \\
\hline
\end{tabular}

The results of maize samples collected during 2017 are summarized in Table 2. ENs were not found in any of the four regions. MON, BEA, and FUS were found in all regions, except for FUS, which was not foundin the sample from North-Backa. All the samples from the South-Banat region were contaminated with MON and BEA. The highest mean levels of MON $(499.00 \mu \mathrm{g} / \mathrm{kg})$ and FUS $(3415.88 \mu \mathrm{g} / \mathrm{kg})$ were recorded in the West-Backa region, while the highest mean level of BEA $(12.26 \mu \mathrm{g} / \mathrm{kg})$ was recorded in the South-Banat region.

Table 2. Occurrence of emerging toxins in maize samples collected in the Republic of Serbia in 2017.

\begin{tabular}{|c|c|c|c|c|c|c|c|}
\hline & MON & BEA & EN A & EN A1 & EN B & EN B1 & FUS \\
\hline \multicolumn{8}{|c|}{ South-Banat region } \\
\hline Average $\pm \mathrm{SD}(\mu \mathrm{g} / \mathrm{kg})$ & $404 \pm 493$ & $12.3 \pm 18.9$ & - & - & - & - & $353 \pm 414$ \\
\hline Range $(\mu \mathrm{g} / \mathrm{kg})$ & $10.4-1803$ & $0.22-67.4$ & - & - & - & - & $63.1-1275$ \\
\hline Samples & 17 & 17 & 17 & 17 & 17 & 17 & 17 \\
\hline Positive samples (\%) & $17(100.0)$ & $17(100.0)$ & 0 & 0 & 0 & 0 & $10(58.8)$ \\
\hline \multicolumn{8}{|c|}{ South-Backa region } \\
\hline Average $\pm \mathrm{SD}(\mu \mathrm{g} / \mathrm{kg})$ & $179 \pm 255$ & $6.30 \pm 16.4$ & - & - & - & - & $468 \pm 843$ \\
\hline Range $(\mu \mathrm{g} / \mathrm{kg})$ & $2.68-1071$ & $0.04-75.9$ & - & - & - & - & $45.5-3018$ \\
\hline Samples & 33 & 33 & 33 & 33 & 33 & 33 & 33 \\
\hline Positive samples (\%) & $20(60.6)$ & $21(63.6)$ & 0 & 0 & 0 & 0 & $12(36.4)$ \\
\hline \multicolumn{8}{|c|}{ West-Backa region } \\
\hline Average $\pm \mathrm{SD}(\mu \mathrm{g} / \mathrm{kg})$ & $499 \pm 880$ & $1.96 \pm 3.88$ & - & - & - & - & $3416 \pm 9786$ \\
\hline Range $(\mu \mathrm{g} / \mathrm{kg})$ & $1.66-2999$ & $0.06-13.4$ & - & - & - & - & 40.6-29512 \\
\hline Samples & 21 & 21 & 21 & 21 & 21 & 21 & 21 \\
\hline Positive samples (\%) & $12(57.1)$ & $11(52.4)$ & 0 & 0 & 0 & 0 & $9(42.9)$ \\
\hline
\end{tabular}


Table 2. Cont.

\begin{tabular}{cccccccc}
\hline & MON & BEA & EN A & EN A1 & EN B & EN B1 & FUS \\
\hline Average $\pm \mathrm{SD}(\mu \mathrm{g} / \mathrm{kg})$ & 221 & 18.3 & \multicolumn{7}{c}{ North-Backa region } & - & - & - & - & - \\
Range $(\mu \mathrm{g} / \mathrm{kg})$ & - & - & - & - & - & - & - \\
Samples & 1 & 1 & 1 & 1 & 1 & 1 & 1 \\
Positive samples $(\%)$ & $1(100.0)$ & $1(100.0)$ & 0 & 0 & 0 & 0 & 0 \\
\hline
\end{tabular}

In 2018, MON was found in all three regions (South-Backa, North-Backa, and South-Banat), BEA and FUS were not found in samples from the South-Banat region and ENs were not present in any sample (Table 3). The mean levels of all tested mycotoxins were highest in the South-Backa region (MON $199.32 \mu \mathrm{g} / \mathrm{kg}$, BEA $4.89 \mu \mathrm{g} / \mathrm{kg}$ and FUS $5793.79 \mu \mathrm{g} / \mathrm{kg}$ ).

Table 3. Occurrence of emerging toxins in maize samples collected in the Republic of Serbia in 2018.

\begin{tabular}{|c|c|c|c|c|c|c|c|}
\hline & MON & BEA & EN A & EN A1 & EN B & EN B1 & FUS \\
\hline \multicolumn{8}{|c|}{ South-Banat region } \\
\hline Average $\pm \mathrm{SD}(\mu \mathrm{g} / \mathrm{kg})$ & $39.5 \pm 44.6$ & - & - & - & - & - & - \\
\hline Range $(\mu \mathrm{g} / \mathrm{kg})$ & $5.19-89.9$ & - & - & - & - & - & - \\
\hline Samples & 6 & 6 & 6 & 17 & 6 & 6 & 6 \\
\hline Positive samples (\%) & $3(50.0)$ & 0 & 0 & 0 & 0 & 0 & 0 \\
\hline \multicolumn{8}{|c|}{ South-Backa region } \\
\hline Average $\pm \mathrm{SD}(\mu \mathrm{g} / \mathrm{kg})$ & $199 \pm 238$ & $4.89 \pm 6.91$ & - & - & - & - & $5794 \pm 14,479$ \\
\hline xRange $(\mu \mathrm{g} / \mathrm{kg})$ & $5.80-857$ & $0.15-21.5$ & - & - & - & - & $63.2-38,610$ \\
\hline Samples & 34 & 34 & 34 & 34 & 34 & 34 & 34 \\
\hline Positive samples (\%) & $16(47.1)$ & $9(26.5)$ & 0 & 0 & 0 & 0 & $7(20.6)$ \\
\hline \multicolumn{8}{|c|}{ North-Backa region } \\
\hline Average $\pm \mathrm{SD}(\mu \mathrm{g} / \mathrm{kg})$ & $34.4 \pm 36.9$ & 3.33 & - & - & - & - & 72.4 \\
\hline Range $(\mu \mathrm{g} / \mathrm{kg})$ & $55.82-88.7$ & - & - & - & - & - & - \\
\hline Samples & 5 & 5 & 5 & 5 & 5 & 5 & 5 \\
\hline Positive samples (\%) & $4(80.0)$ & $1(20.0)$ & 0 & 0 & 0 & 0 & $1(20.0)$ \\
\hline
\end{tabular}

\subsection{Climate Conditions}

Reports from the Republic Hydrometeorological Service of Serbia [30] showed that the vegetation period of 2016 (April-September) in the territory of Serbia was warmer with somewhat higher precipitation than the long-term average. The deviation of mean daily temperatures during the vegetation period showed positive values $\left(0.8^{\circ} \mathrm{C}\right.$ to $\left.1.6^{\circ} \mathrm{C}\right)$. The standardized precipitation index (SPI-3), determined for the summer period from 1 June to 31 August, showed normal humidity conditions for most of the territory of Vojvodina. However, in some parts of Vojvodina, moderate to extremely humid conditions were recorded (Figure 1B). Such conditions were registered in the Middle-Banat and West-Backa regions, and some parts of the South-Backa and South-Banat regions. In some production areas, strong winds and hail storms were recorded and certainly contributed to the damage of the grains and the occurrence of fungi on crops. The moisture in deeper soil layers in the middle of June was significantly reduced in Vojvodina as a result of a weaker inflow of precipitation in these areas.

If the weather conditions were observed in more detail, warm but unstable weather prevailed during the transition from May to June, and the agrometeorological conditions allowed the intensive development of maize. The trend of variable but warm weather continued in June. In the middle of the month, due to the influx of very hot air, the temperatures were considerably above the average for this period of the year. Maximum daily temperatures reached $36^{\circ} \mathrm{C}$ on some days [30]. Thermal conditions were favorable for the intensive development of spring agricultural crops. By the end of the first decade of August, the weather was mostly dry and stable, but since the beginning of the second decade of August, the air temperatures moved around and were below average values. Maximum air temperatures were up to $28^{\circ} \mathrm{C}$, while the minimum morning temperatures were significantly below the average values for this time of the year [30]. Significant precipitation, mostly rain showers, was 
recorded on the territory of the entire country. During July and August, 2 to 3 times more rain was registered in the territory of Serbia compared to the average quantities.
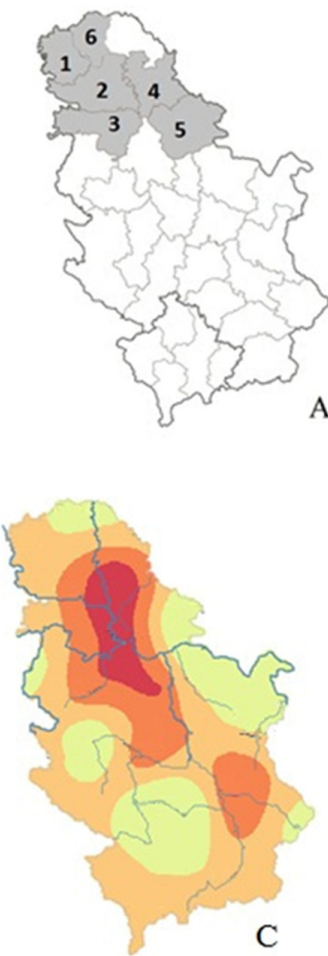

A

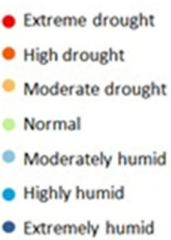

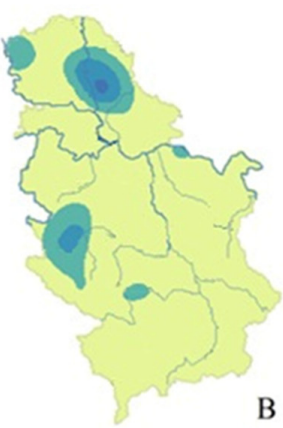

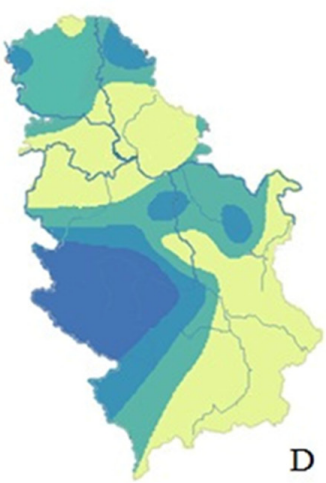

Figure 1. Regions of sample origin: 1-West-Backa, 2-South-Backa, 3-Srem, 4-Middle-Banat, 5-South-Banat, 6-North-Backa. (A) Humidity conditions in Serbia based on the Standardized Precipitation Index (SPI-3) determined for the summer period from 1 June to 31 August in 2016 (B) Reproduced from Agrometeorološki uslovi u proizvodnoj 2015/2016 godini, 2017, Republic Hydrometeorological Service of Serbia [30], 2017 (C) Reproduced from Agrometeorološki uslovi u proizvodnoj 2016/2017 godini, 2018, Republic Hydrometeorological Service of Serbia [31], and 2018 (D) Reproduced from Agrometeorološki uslovi u proizvodnoj 2017/2018, 2019, Republic Hydrometeorological Service of Serbia [32].

Detailed data on precipitation and temperature obtained from Metosßautomatic weather stations (Metos@, Pessl Instruments, Weiz, Austria) in the observed regions in 2016 were compared to the multiannual average for 1981-2010 [33].Precipitation data (Figure 2) show that the Middle-Banat region, which overall was the most contaminated with emerging Fusarium toxins, and Srem, which showed the highest values of toxins, had precipitation values higher than the average in June, but they were noticeably lower in July. Average daily air temperature data (Figure 2) show that the temperature was around or slightly above the long-term average until August, when the temperature decreased. Average daily air temperatures were similar in all regions.

Reports from the Republic Hydrometeorological Service of Serbia [31] showed that the vegetation period of 2017 (April-September) was warmer and dryer than the multiannual average. The mean daily temperatures were $0.9-1.7^{\circ} \mathrm{C}$ higher than the average, while precipitation was $20 \%$ lower than the average. SPI-3 showed extreme drought in the South-Banat region, while other observed regions were affected by high to moderate drought (Figure 1C).

The vegetation period started with unusually cold weather in April, but the weather conditions quickly normalized and became optimal for plant development during May [31]. During June, mean daily temperatures were higher than the average [31]. Maximum daily temperatures reached over 35 ${ }^{\circ} \mathrm{C}$ on some days, especially during the first and the last decade of the month. Hot weather continued during July. In most regions, precipitation was below the multiannual average, especially in the 
South-Banat region, where it was $50 \%$ lower than the average. The temperatures at the beginning of August were extremely high $\left(38-42{ }^{\circ} \mathrm{C}\right)$ and higher than the average during the whole month [31]. Most regions were affected with drought, except the South-Banat region, which had 50\% more rainfall than the average.

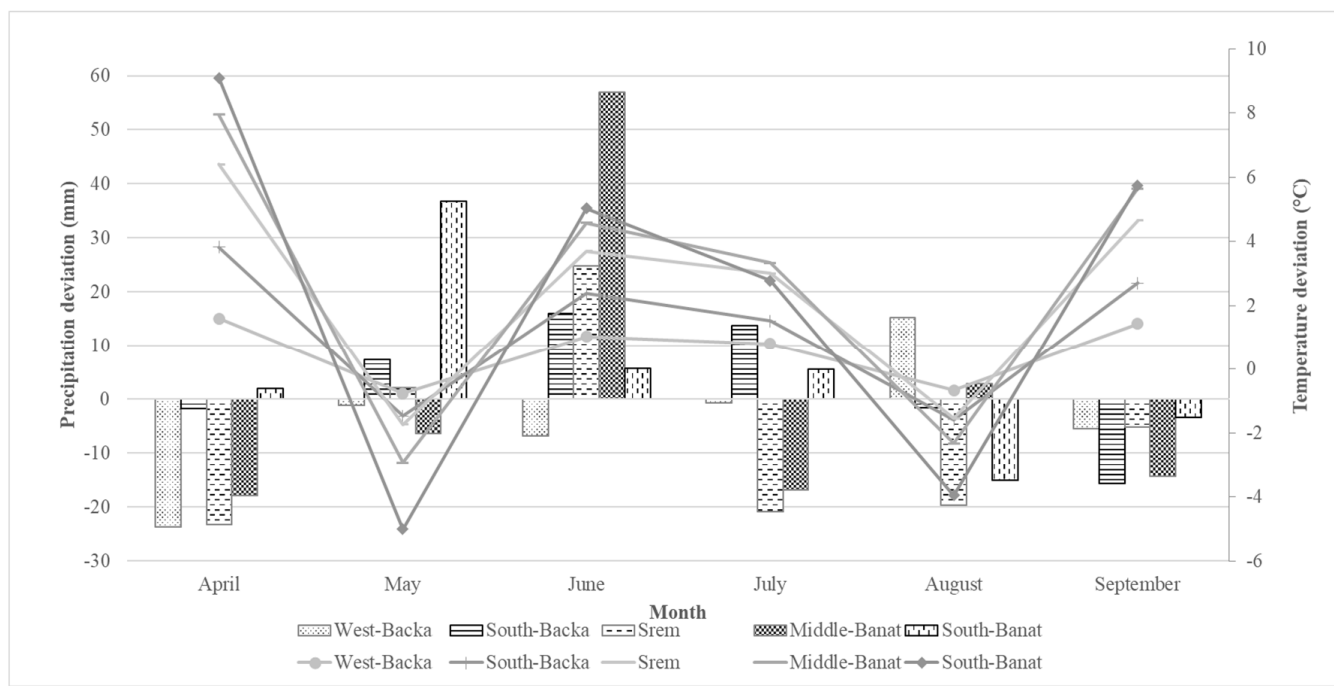

Figure 2. Deviation of total rainfall amount (columns) and average daily air temperature (lines) from the multiannual average (1981-2010) in 2016.

Precipitation and average daily air temperature data obtained from Metos@automatic weather stations (Metos $®$, Pessl Instruments, Weiz, Austria) in the observed regions during 2017 were compared to the multiannual average from 1981-2010 [33]. Precipitation data (Figure 3) showed that all regions had lower precipitation than the average during June. This trend continued through July for all regions except West-Backa, where high occurrences of MON and FUS were observed. The deviation of average daily air temperature (Figure 3) shows that temperature in April was lower than the multiannualaverage in all regions. During May, it was slightly above the multiannualaverage in all regions except South-Banat. In June the temperature was $1.4-2.4{ }^{\circ} \mathrm{C}$ higher than the average. Temperatures continued to be above the average until September.

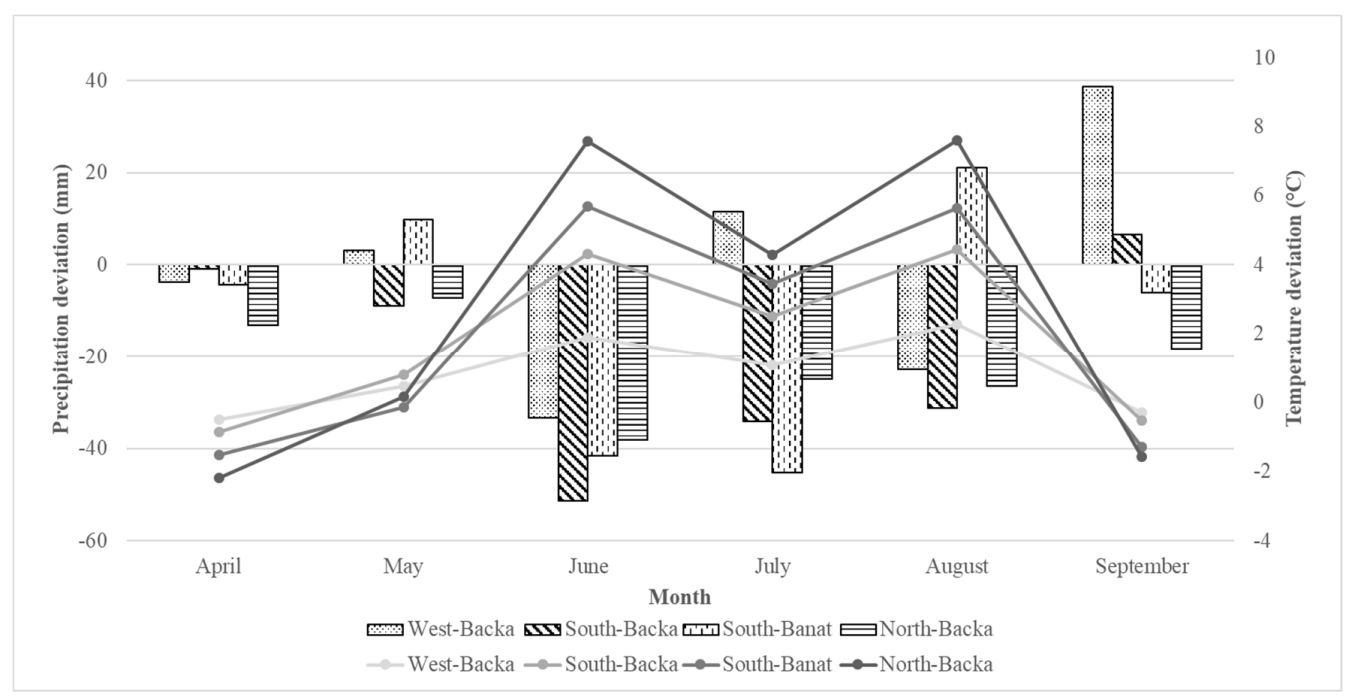

Figure 3. Deviation of total rainfall amount (columns) and average daily air temperature (lines) from multiannual average (1981-2010) in 2017. 
According to reports from the Republic Hydrometeorological Service of Serbia [32], the vegetation period in 2018 (April-September) was $1.8-2.6^{\circ} \mathrm{C}$ warmer than the multiannual average. SPI-3 showed normal to moderately humid weather conditions in all observed regions (Figure 1D).

The vegetation period started with unusually warm weather in April when the mean daily temperature was $4-5{ }^{\circ} \mathrm{C}$ above the multiannualaverage [32]. During May, weather conditions were optimal for plant growth. In the beginning of June, maximum daily temperatures were high $\left(28-34{ }^{\circ} \mathrm{C}\right)$, but temperature decreased in the last decade of the month when maximum daily temperatures were in the range from $19{ }^{\circ} \mathrm{C}$ to $24^{\circ} \mathrm{C}$ [32]. Frequent rain showers were recorded during June and continued through July. Warm weather with temperatures above multiannualaverage continued through August and September [32].

The deviation of precipitation and average daily air temperature data collected from Metos (Bautomatic weather stations (Metos@, Pessl Instruments, Weiz, Austria) during 2018 from the multiannual average of 1981-2010 [33] was observed. Precipitation data (Figure 4) showed that precipitation was below average during the whole vegetation period in the North-Backa region. Precipitation was lower than the average in all three regions in April, May, August, and September. In June, precipitation was above average in the South-Backa and South-Banat regions. South-Backa was the only region where high precipitation continued in July.Average daily air temperature data (Figure 4) show that the temperature was above the long-term average in all regions during April and May. Temperature decreased during June and in July, reaching the multiannualaverage value in the South-Backa region, while the North-Backa and South-Banat regionswere below average. In August and September, the temperature increased again above the multiannual average in all observed regions.

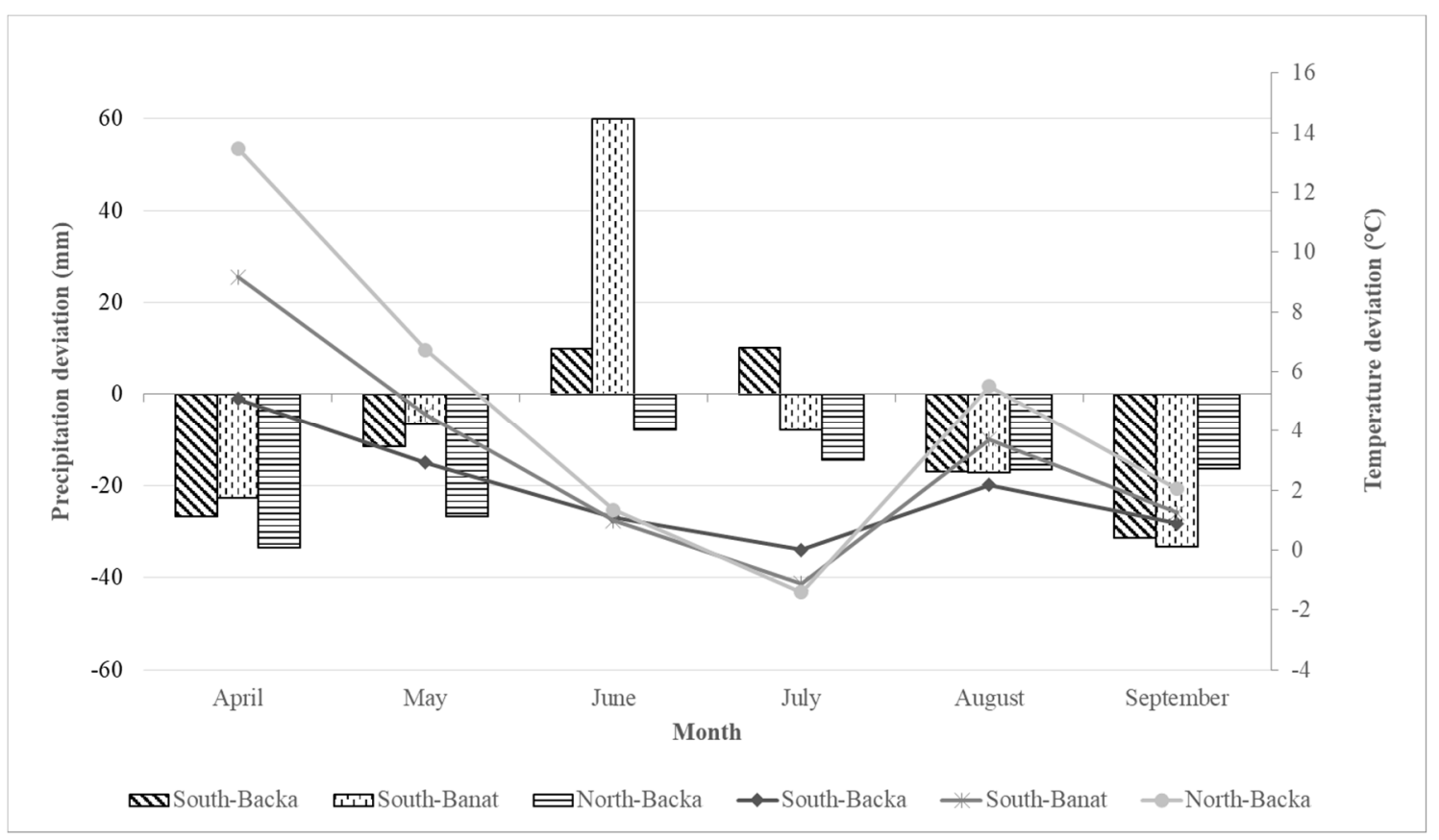

Figure 4. Deviation of total rainfall amount (columns) and average daily air temperature (lines) from the multiannual average (1981-2010) in 2018.

\subsection{Statistical Analysis}

The Kruskal-Wallis test (95\% confidence level) found significant differences in MON levels deriving from different years and different regions. Additionally, MON levels significantly differed when compared in terms of average seasonal temperature and precipitation. For FUS, significant differences were found between years, average seasonal temperatures and precipitation, but not between regions. Statistically significant differences in BEA levels were found between years and regions. Furthermore, the Spearman correlation determined a slightly moderate negative linear 
correlation between average seasonal temperatures and mycotoxin contamination levels $(r=-0.41$ for MON, $r=-0.5$ for BEA, and $r=-0.45$ for FUS). For monthly weather data, only temperatures in May showed a moderate negative linear correlation $(r=-0.5$ for MON, $r=-0.58$ for BEA, and $\mathrm{r}=-0.48$ for FUS), while precipitation in May showed a moderate positive linear correlation with contamination levels of observed mycotoxins ( $r=0.51$ for $\mathrm{MON}, r=0.59$ for BEA, and $r=0.49$ for FUS). Stepwise regression showed (with 95\% confidence level) that air temperatures from May to August had statistically significant differences in MON levels. For FUS, temperatures and precipitation in any month, as well as average values for the whole growing season, did not show statistically significant differences among contamination levels. May temperatures had a statistically significant difference in BEA levels. The adjusted R-squared values were between 0.101 and 0.2278 and showed that these models cannot be used as prediction models; however, they gave insight about statistically significant variables that influence mycotoxin contamination.

\section{Discussion}

Sutton [34] explained that for maize, Fusarium infection of the ear most frequently takes place through the tip of the ear when the fungi penetrate through the silk during maize flowering. Very humid weather during the period from silking to ripening enables ear contamination [35]. The ear is the most susceptible to contamination at the beginning of silking, while the susceptibility decreases with silk aging [36,37]. The silking period in the climatic region of Serbia takes place during July and the first half of August.

According to the Republic Hydrometeorological Service of Serbia [30], most of the critical period for Fusarium infection of maize (July-August) in 2016 was characterized as dry and stable weather. However, since the beginning of the second decade of August, air temperatures ranged around and below average values [30]. Maximum air temperatures were up to a maximum of $28{ }^{\circ} \mathrm{C}$, while the minimum morning temperatures were significantly below the average values for this time of the year. However, moderate to extremely humid conditions occurred during the summer of 2016 in the Middle-Banat and West-Backa regions and some parts of the South-Backa and South-Banat regions, which may have led to Fusarium fungi growth and the consequent production of mycotoxins. Moreover, cool, cloudy and humid weather during July and August did not favor agricultural crops and such conditions probably caused plant stress and higher susceptibility to Fusarium infection.

In 2017, precipitation was lower than the multiannual average during summer months in all regions except South-Banat, where high levels of BEA were recorded. High precipitation in these two regions during silking (July and beginning of August), when the maize is the most susceptible to Fusarium infections were favorable for fungal development, may have led to high levels of emerging toxins in samples from these regions.

High precipitation during June 2018 in the South-Backa and South-Banat regions and during July 2018 in South-Backa resulted in South-Backa having the highest mean levels of MON, BEA, and FUS. Warm weather during July, together with high humidity in the South-Backa region enabled Fusarium infection of the ears, which may be related to the high mycotoxin contamination of samples from this region.

Emerging fusariotoxins were mostly investigated in Mediterranean countries. Juan et al. [22] analyzed 93 samples of organic cereals and organic cereal products from several local markets in Italy for the presence of different mycotoxins, including BEA, EN A, EN A1, EN B, EN B1. The authors found that levels of some emerging Fusarium mycotoxins ranged as follows: BEA 6.7-41 $\mu \mathrm{g} / \mathrm{kg}, \mathrm{EN}$ A 7.2-29.8 $\mu \mathrm{g} / \mathrm{kg}$, EN A1 5.3-64.3 $\mu \mathrm{g} / \mathrm{kg}$, EN B 5.5-102 $\mu \mathrm{g} / \mathrm{kg}$ and EN B1 5.5-33.1 $\mu \mathrm{g} / \mathrm{kg}$. Among the commodities, the occurrence was the highest in wheat samples. Serrano et al. [21], investigated fusariotoxins' occurrence in the Mediterranean area. They found that BEA was present in 2 of 14 maize samples and in 1 of 22 maize-based products. Obtained levels were 2.1 and $73.9 \mu \mathrm{g} / \mathrm{kg}$ for maize and $5.2 \mu \mathrm{g} / \mathrm{kg}$ for maize-based products, respectively. A high divergence among detected BEA levels was also found in this study $(0.03-136 \mu \mathrm{g} / \mathrm{kg})$. Later, Serrano et al. compared levels of emerging 
fusariotoxins between organic and conventional pasta in Spain [38]. They found that organic pasta was more contaminated than the conventional type. Contamination levels were $0.10-20.96 \mu \mathrm{g} / \mathrm{kg}$ for BEA, and 0.05-8.02 $\mu \mathrm{g} / \mathrm{kg}$ for FUS, while ENs levels were $0.25-979.56 \mu \mathrm{g} / \mathrm{kg}$. Remarkably high levels of emerging mycotoxins in raw cereals were found in Morocco by Zinedine et al. [39]. EN A1 was predominant among ENs with a presence in 39\% of samples and levels ranging from 14 to $445 \mathrm{mg} / \mathrm{kg}$. BEA was found in $26.5 \%$ of samples, with levels ranging from 1 to $59 \mathrm{mg} / \mathrm{kg}$, while FUS was present in $7.8 \%$ of samples (levels from 0.6 to $2 \mathrm{mg} / \mathrm{kg}$ ). Regarding maize samples, $42 \%$ contained ENs with mean levels of $207 \mathrm{mg} / \mathrm{kg}$ (EN A1), $54 \mathrm{mg} / \mathrm{kg}$ (EN B), $8 \mathrm{mg} / \mathrm{kg}$ (EN B1), while EN A was not detected. A similar situation was observed in cereals from the Spanish market [40]. The authors reported very a high presence of ENs $(73.4 \%)$, wherein EN A1 was the most frequent with the highest levels $(33.36-814.42 \mathrm{mg} / \mathrm{kg})$. BEA was found in $32.8 \%$ of samples in the range of $0.51-11.78 \mathrm{mg} / \mathrm{kg}$, and FUS levels were between $1.01-6.63 \mathrm{mg} / \mathrm{kg}$ with the presence in $7.8 \%$ of samples. In maize samples, the presence of ENs was $89 \%$, BEA was found in $21 \%$ and FUS was in only one sample; on the other hand, ENs were found only during 2016 in this study, but not in any samples from 2017 and 2018, while BEA and FUS were detected every year. The highest mean level in maize was obtained for EN A1 of 813.01 $\mathrm{mg} / \mathrm{kg}$, while in this survey the highest mean level of EN A1 was only $9.30 \mu \mathrm{g} / \mathrm{kg}$. In another study in Morocco on maize-based breakfast cereals, Mahnine et al. [41] obtained mean levels of $113 \mathrm{mg} / \mathrm{kg}$ for EN A1 and $20.1 \mathrm{mg} / \mathrm{kg}$ for EN B1, respectively, while EN A, EN B, FUS, and BEA were below LOQ in all samples. Tunisian cereals were highly contaminated as well. Maize-based cereals only contained EN A1 and ENB1 with mean levels of $113 \mathrm{mg} / \mathrm{kg}$ and $20.1 \mathrm{mg} / \mathrm{kg}$. Oueslati et al. [20] obtained the presence of ENs in $96 \%$ of samples, where once more EN A1 was predominant (92.1\%). Mean values were the highest in the case of EN A1 (up to $480 \mathrm{mg} / \mathrm{kg}$ ). Only 3 samples of maize were analyzed. Two samples were positive, one with EN A1 $(29.6 \mathrm{mg} / \mathrm{kg})$ and another contained EN B1 $(17.0 \mathrm{mg} / \mathrm{kg})$. Notably, none of these authors analyzed results along with the weather conditions. Emerging fusariotoxins were also studied in rice. In Morocco, considerable contamination with ENs and BEA was revealed, but not with FUS [19]. In rice samples from Iran, a significant presence was found only in the case of BEA (40\%), but in very low amounts [23].

Emerging fusariotoxins were also studied in some non-Mediterranean European countries. Goertz et al. [42] investigated the contamination of different maize hybrids in Germany during 2006 and 2007. BEA was found in 52\% of samples from 2006 and in 33\% of samples from 2007. Mean levels were $390 \mu \mathrm{g} / \mathrm{kg}$ and $240 \mu \mathrm{g} / \mathrm{kg}$, respectively. MON was detected in $45 \%$ and $43 \%$ of samples, respectively, with mean values of $280 \mu \mathrm{g} / \mathrm{kg}$ and $110 \mu \mathrm{g} / \mathrm{kg}$, respectively. Among EN, only EN B was investigated. Although its presence was relatively high $(41 \%$ and $30 \%$, respectively) the levels were the lowest (mean of $70 \mu \mathrm{g} / \mathrm{kg}$ and $160 \mu \mathrm{g} / \mathrm{kg}$, respectively) among investigated emerging fusariotoxins. The authors explained that moderate temperatures and frequent precipitation recorded during early growth stages in 2007 were favorable for Fusarium growth. This is in accordance with the results of correlation analysis in this study, which showed a moderately negative correlation between May temperatures and toxin contamination, together with a moderately positive correlation between May precipitation and toxin contamination. However, a higher mycotoxin presence and higher contamination levels in Germany were found in samples from 2006, which they associated with maize exposure to drought stress in July and September 2006. In Norway, Uhlig et al. [43] investigated MON occurrence in Norwegian grain (oats, barley, and wheat) during a three-year period (2000-2002). MON was found in $46 \%$ of samples and the obtained levels were between 43 and $950 \mu \mathrm{g} / \mathrm{kg}$. The authors noted that the highest prevalence of MON was found in the 2002 season (67\%), along with the highest concentration. In Poland, Chelkowski et al. [44] detected ENs and BEA in 18 out of 27 maize samples (levels of $0.8-46.0 \mathrm{mg} / \mathrm{kg}$ ). Unfortunately, in both studies, the weather conditions were not discussed.

To the best of our knowledge, studies on emerging Fusarium toxins in Serbia have not been done to date. On the other hand, some studies have occurred in surrounding countries. In Romania, Stanciu et al. [45] found that ENs were the most frequent (73\%) mycotoxins in both wheat and wheat flour, while EN B was detected the most (71\%). The highest observed concentration was $407 \mu \mathrm{g} / \mathrm{kg}$ in 
wheat samples. Mean values were $19 \mu \mathrm{g} / \mathrm{kg}$ in wheat flour and $128 \mu \mathrm{g} / \mathrm{kg}$ in wheat. In neighboring Croatia, Jurjević et al. [46] investigated BEA presence in 209 maize samples originating from the 1996 and 1997 growing seasons. The authors found that $17.4 \%$ of samples from 1996 contained BEA at the mean level of $393 \mu \mathrm{g} / \mathrm{kg}$ and maximum concentration of $1864 \mu \mathrm{g} / \mathrm{kg}$. In samples from 1994, only one of 104 samples contained BEA.

Based on the obtained results and available published data, the results from this study are in accordance with those found in Croatia, Italy, and Germany, while results from Poland, Spain, Morocco, and Tunisia are one order of magnitude higher. Unfortunately, studies from Romania, Norway, and Iran did not include maize or maize-based products and therefore a valid comparison cannot be made.

\section{Conclusions}

The main source of emerging Fusarium mycotoxins are cereals that are used in food and feed production, and they may thus pose a potential risk for human and animal health. Since environmental conditions in Serbia are favorable for the occurrence of mycotoxigenic fungi, monitoring of "traditional" but also "emerging" Fusarium toxins is essential for producing safe food and feed. The results indicated that most attention should be paid to fusaproliferin (FUS) and moniliformin (MON). Additionally, monitoring studies for emerging Fusarium mycotoxins are necessary for legislative purposes, because in the near future appropriate maximum contamination levels should be set for several mycotoxins by relevant authorities [38].

\section{Materials and Methods}

\subsection{Samples}

In total, 190 representative samples from commercial fields in Serbia were analyzed. Samples were collected during harvest in the northern Serbian province of Vojvodina, which is the country's most important agricultural area, over three years: 73 samples from 28 localities in 2016, 72 samples from 12 localities in 2017 and 45 samples from 13 localities in 2018. Localities were clustered based on their administrative area into 6 regions: West-Backa, South-Backa, Srem, Middle-Banat, South-Banat, and North-Backa (Figure 1A).

Each sample was transported to the laboratory immediately after sampling and stored in a freezer at $-20{ }^{\circ} \mathrm{C}$ until analysis. Prior to analysis, the samples were allowed to reach room temperature. All samples were milled on a laboratory mill so that $>93 \%$ passed through a sieve with a pore diameter of $0.8 \mathrm{~mm}$ and a portion was taken for analysis.

\subsection{Extraction and Mycotoxin Analysis in Maize Samples}

Five grams of each milled sample were extracted using a $20 \mathrm{~mL}$ extraction solvent (acetonitrile-water-acetic acid (VWR, Vienna, Austria), 79:20:1, v/v/v) followed by a $1+1$ dilution using acetonitrile-water-acetic acid (VWR, Vienna, Austria) (20:79:1, v/v/v) and a direct injection of $5 \mu \mathrm{L}$ diluted extract.

Liquid chromatography-tandem mass spectrometry (LC-MS/MS) screening of target fungal metabolites was performed at theInstitute of Bioanalytics and Agro-Metabolomics, Department of Agrobiotechnology (IFA-Tulln), University of Natural Resources and Life Sciences, Vienna, with a QTrap 5500 LC-MS/MS System (Applied Biosystems, Foster City, CA, USA) equipped with a Turbolon Spray electrospray ionization (ESI) source and a 1290 Series HPLC System (Agilent, Waldbronn, Germany). Chromatographic separation was performed at $25^{\circ} \mathrm{C}$ on a Gemini ${ }^{\circledR} \mathrm{C}_{18}$-column, $150 \times 4.6 \mathrm{~mm}$ i.d., $5 \mu \mathrm{m}$ particle size, equipped with a $\mathrm{C}_{18} 4 \times 3 \mathrm{~mm}$ i.d. security guard cartridge (all from Phenomenex, Torrance, CA, USA). The chromatographic method, chromatographic and mass spectrometric parameters, as well as the method validation data, are described by Malachova et al. [47]. Electrospray ionization-tandem mass spectrometry (ESI-MS/MS) was performed in the time-scheduled multiple reaction monitoring (MRM) mode both in positive and negative polarities in two separate chromatographic runs per sample 
by scanning two fragmentation reactions per analyte. The MRM detection window of each analyte was set to its expected retention time of $\pm 27 \mathrm{sec}$ and $\pm 48 \mathrm{sec}$ in the positive and the negative mode, respectively. Confirmation of a positive analyte identification was obtained by the acquisition of two MRMs per analyte (excepting moniliformin, which exhibits only one fragment ion), which yielded 4.0 identification points according to commission decision 2002/657/EC. In addition, the LC retention time and the intensity ratio of the two MRM transitionswas in accordance with the related values of an authentic standard within $0.1 \mathrm{~min}$ and $30 \%$ rel., respectively.

Quantification was based on an external calibration using a serial dilution of a multianalyte stock solution, and results were corrected for apparent recoveries. The accuracy of the method is verified on a continuous basis by regular participation in proficiency testing schemes $[47,48]$ organized by BIPEA (Gennevilliers, France). Based on the submitted results, a general expanded measurement uncertainty of $50 \%$ has been determined [49]. In the case of the 175 results already submitted for maize and maize-based feed, 168 results were in the satisfactory range ( $z$-score between -2 and 2 ).

\subsection{Statistical Analysis}

Statistical analysis (Supplementary Materials) was performed using the computing environment $R$ ( $R$ Core Team, Vienna, Austria) [50] on the data from regions where samples were collected during all three years of research (South-Backa and South-Banat). The Shapiro-Wilk normality test was used to check the distribution of the data. Since the data were not normally distributed, nonparametric tests were used for further analysis. The Kruskal-Wallis test was used to check whether the mean ranks of the mycotoxin levels were the same in all groups. Spearman's correlation was used to determine the correlation between climate conditions and mycotoxin contamination levels. Furthermore, Stepwise regression with backward steps was used to obtain the optimal model and significant months in terms of temperature and precipitation values that influence mycotoxin levels.

Supplementary Materials: The following are available online at http://www.mdpi.com/2072-6651/11/6/357/s1, Figure S1. Spearman Correlation Results $(r)$.

Author Contributions: Conceptualization, I.J. and F.B.; Data curation, T.D., S.K., Z.S., and A.S.; Formal analysis, T.D., S.K., and D.G.; Funding acquisition, I.J., R.K., and F.B.; Investigation, R.K., M.S., Z.S., D.G., and A.S.; Methodology, R.K., M.S., and D.G.; Project administration, I.J. and F.B.; Resources, I.J. and F.B.; Software, T.D. and S.K.; Supervision, I.J., R.K., and F.B.; Validation, I.J., R.K. and M.S.; Visualization, T.D. and S.K.; Writing—originaldraft, T.D. and S.K.; Writing—review and editing, I.J., R.K., F.B., and Z.S.

Funding: This research was funded by MyToolBox (EU's Horizon 2020 research and innovation programme, agreement No 678012), research project of the Ministry of Education, Science and Technological Development, Republic of Serbia (project III 46005) and Provincial Secretariat for Higher Education and Scientific Research of the Autonomous Province of Vojvodina through the project "Application of novel and conventional processes for removal of most common contaminants, mycotoxins and salmonella, in order to produce safe animal feed inthe territory of AP Vojvodina", Project No. 114-451-2505/2016-01.

Conflicts of Interest: The authors declare no conflict of interest.

\section{References}

1. Jestoi, M. Emerging Fusarium mycotoxins fusaproliferin, beauvericin, enniatins, and moniliformin: A review. Crit. Rev. FoodSci. Nutr. 2008, 48, 21-49. [CrossRef] [PubMed]

2. Kumar, V.; Basu, M.S.; Rajendran, T.P. Mycotoxin research and mycoflora in some commercially important agricultural commodities. Crop Prot. 2008, 27, 891-905. [CrossRef]

3. Kovalsky, P.; Kos, G.; Nährer, K.; Schwab, C.; Jenkins, T.; Schatzmayr, G.; Sulyok, M.; Krska, R. Co-occurrence of regulated, masked and emerging mycotoxins and secondary metabolites in finished feed and maize-An extensive survey. Toxins 2016, 8, 363. [CrossRef] [PubMed]

4. Burmeister, H.R.; Ciegler, A.; Vesonder, R.F. Moniliformin, a metabolite of Fusarium moniliforme NRRL 6322: Purification and toxicity. Appl. Environ. Microbiol. 1979, 37, 11-13. [PubMed]

5. Cole, R.J.; Kirksey, J.W.; Cutler, H.G.; Doupnik, B.L.; Peckham, J.C. Toxin from Fusarium moniliforme: Effects on plants and animals. Science 1973, 179, 1324-1326. [CrossRef] [PubMed] 
6. Calo, L.; Fornelli, F.; Ramiers, R.; Nenna, S.; Tursi, A.; Caiaffa, M.F.; Macchia, L. Cytotoxic effects of the mycotoxin beauvericin to human cell lines of myeloid origin. Pharmacol. Res. 2004, 49, 73-77. [CrossRef] [PubMed]

7. Ivanova, L.; Skjerve, E.; Eriksen, G.S.; Uhlig, S. Cytotoxicity of enniatins A, A1, B, B1, B2 and B3 from Fusarium avenaceum. Toxicon 2006, 47, 868-876. [CrossRef] [PubMed]

8. Jow, G.M.; Chou, C.J.; Chen, B.F.; Tsai, J.H. Beauvericin induces cytotoxic effects in human acute lymphoblastic leukemia cells through cytochrome c release, caspase 3 activation: The causative role of calcium. Cancer Lett. 2004, 216, 165-173. [CrossRef]

9. Ferrer, E.; Juan-García, A.; Font, G.; Ruiz, M.J. Reactive oxygen species induced by beauvericin, patulin and zearalenone in CHO-K1 cells. Toxicol. In Vitro 2009, 23, 1504-1509. [CrossRef]

10. Ritieni, A.; Fogliano, V.; Randazzo, G.; Scarallo, A.; Logrieco, A.; Moretti, A.; Manndina, L.; Bottalico, A. Isolation and characterization of fusaproliferin, a new toxic metabolite from Fusarium proliferatum. Nat. Toxins 1995, 3, 17-20. [CrossRef]

11. Tomoda, H.; Huang, X.H.; Nishida, J.; Cao, H.; Nagao, R.; Okuda, S.; Tanaka, H.; Omura, S.; Arai, H.; Inoue, K. Inhibition of acyl-CoA: Cholesterol acyltransferase activity by cyclodepsipeptide antibiotics. J. Antibiot. 1992, 45, 1626-1632. [CrossRef] [PubMed]

12. Macchia, L.; Di Paola, R.; Fornelli, F.; Nenna, S.; Moretti, A.; Napoletano, R.; Logrieco, A.; Caiaffa, M.F.; Bottalico, A. Cytotoxicity of beauvericin to mammalian cells. In Abstracts of the International Seminaron Fusarium: Mycotoxins, Taxonomyand Pathogenicity, Martina Franca, Italy, 9-13 May 1995; Stampasud: Mottola, Italy, 1995; pp. 72-73.

13. Fornelli, F.; Minervini, F.; Logrieco, A. Cytotoxicity of fungal metabolites to lepidopteran (Spodopterafrugiperda) cell line (SF-9). J. Invertebr. Pathol. 2004, 85, 74-79. [CrossRef] [PubMed]

14. Ojcius, D.M.; Zychlinsky, A.; Zheng, L.M.; Young, J.D.E. Ionophore induced apoptosis: Role of DNA fragmentation and calcium fluxes. Exp. Cell Res. 1991, 197, 43-49. [CrossRef]

15. Randazzo, G.; Fogliano, V.; Ritieni, A.; Mannina, L.; Rossi, E.; Scarallo, A.; Segre, A.L. Proliferin, a new sesterterpene from Fusarium proliferatum. Tetrahedron 1993, 49, 10883-10896. [CrossRef]

16. Logrieco, A.; Moretti, A.; Fornelli, F.; Fogliano, V.; Ritieni, A.; Caiaffa, M.F.; Randazzo, G.; Bottalico, A.; Macchia, L. Fusaproliferin production by Fusarium subglutinans and its toxicity to Artemia salina, SF-9 insect cells, and IARC/LCL 171 human B lymphocytes. Appl. Environ Microbiol. 1996, 62, 3378-3384. [PubMed]

17. Ritieni, A.; Monti, S.M.; Randazzo, G.; Logrieco, A.; Moretti, A.; Peluso, G.; Ferracane, R.; Fogliano, V. Teratogenic effects of fusaproliferin on chicken. J. Agric. Food Chem. 1997, 45, 3039-3043. [CrossRef]

18. Kriek, N.P.J.; Marasas, W.F.O.; Steyn, P.S.; Van Rensburg, S.J.; Steyn, M. Toxicity of a moniliformin-producing strain of Fusarium moniliforme var. subglutinans isolated from maize. Food Cosmet. Toxicol. 1977, 15, 579-587. [CrossRef]

19. Sifou, A.; Meca, G.; Serrano, A.B.; Mahnine, N.; El Abidi, A.; Mañes, J.; El Azzouzi, M.; Zinedine, A. First report on the presence of emerging Fusarium mycotoxins enniatins (A, A1, B, B1), beauvericin and fusaproliferin in rice on the Moroccan retail markets. Food Control 2011, 22, 1826-1830. [CrossRef]

20. Oueslati, S.; Meca, G.; Mliki, A.; Ghorbel, A.; Mañes, J. Determination of Fusarium mycotoxins enniatins, beauvericin and fusaproliferin in cereals and derived products from Tunisia. Food Control 2011, 22, 1373-1377. [CrossRef]

21. Serrano, A.; Font, G.; Ruiz, M.; Ferrer, E. Co-occurrence and risk assessment of mycotoxins in food and diet from Mediterranean area. Food Chem. 2012, 135, 423-429. [CrossRef]

22. Juan, C.; Ritieni, A.; Mañes, J. Occurrence of Fusarium mycotoxins in Italian cereal and cereal products from organic farming. Food Chem. 2013, 141, 1747-1755. [CrossRef] [PubMed]

23. Nazari, F.; Sulyok, M.; Kobarfard, F.; Yazdanpanah, H.; Krska, R. Evaluation of emerging Fusarium mycotoxins beauvericin, enniatins, fusaproliferin and moniliformin in domestic rice in Iran. Iran. J. Pharm. Res. 2015, 14, 505-512. [PubMed]

24. EFSA CONTAM Panel (EFSA Panel on Contaminants in the Food Chain). Scientific Opinion on the risks to human and animal health related to the presence of beauvericin and enniatins in food and feed. EFSA J. 2014, 12, 3802. [CrossRef]

25. Statistical Office of the Republic of Serbia. Statistical Yearbook of Serbia 2017. Available online: http: //publikacije.stat.gov.rs/G2017/Pdf/G20172022.pdf (accessed on 6 September 2018). 
26. Statistical Office of the Republic of Serbia. Statistical Yearbook of Serbia 2018. Available online: http: //publikacije.stat.gov.rs/G2018/Pdf/G20182051.pdf (accessed on 12 February 2019).

27. Statistical Office of the Republic of Serbia. Production of Wheat and Early Fruit and the Expected Yield of Late Crops, Fruit and Grape 2018. Available online: http://publikacije.stat.gov.rs/G2018/Pdf/G20181261.pdf (accessed on 26 September 2018).

28. Index Mundi: Corn Exports by Country 2018. Available online: http://www.indexmundi.com/agriculture/ ?commodity=corn\&graph=exports (accessed on 8 March 2019).

29. Index Mundi: Corn Production by Country 2018. Available online: http://www.indexmundi.com/agriculture/ ?commodity=corn\&graph=production (accessed on 8 March 2019).

30. Republic Hydrometeorological Service of Serbia. Agrometeorološki uslovi u proizvodnoj 2015/2016 godini na teritoriji Republike Srbije. Available online: http://www.hidmet.gov.rs/podaci/agro/ciril/AGROveg2016.pdf (accessed on 23 September 2017).

31. Republic Hydrometeorological Service of Serbia. Agrometeorološki uslovi u proizvodnoj 2016/2017 godini na teritoriji Republike Srbije. Available online: http://www.hidmet.gov.rs/podaci/agro/ciril/AGROveg2017.pdf (accessed on 1 November 2018).

32. Republic Hydrometeorological Service of Serbia. Agrometeorološki uslovi u proizvodnoj 2017/2018 godini na teritoriji Republike Srbije. Available online: http://www.hidmet.gov.rs/podaci/agro/godina.pdf (accessed on 20 February 2019).

33. Republic Hydrometeorological Service of Serbia. Multiannual Average of Meteorological Parameters (1981-2010). Available online: http://www.hidmet.gov.rs/ciril/meteorologija/klimatologija_srednjaci.php (accessed on 20 February 2019).

34. Sutton, J.C. Epidemiology of wheat head blight and maize ear rot caused by Fusarium graminearum. Can. J. Plant Pathol. 1982, 4, 195-209. [CrossRef]

35. Vigier, B.; Reid, L.M.; Seifert, K.A.; Stewart, D.W.; Hamilton, R.I. Distribution and prediction of Fusarium species associated with maize ear rot in Ontario. Can. J. Plant Pathol. 1997, 19, 60-65. [CrossRef]

36. Reid, L.M.; Bolton, A.T.; Hamilton, R.I.; Woldemariam, T.; Mather, D.E. Effect of silk age on resistance of maize to Fusarium graminearum. Can. J. Plant Pathol. 1992, 14, 293-298. [CrossRef]

37. Reid, L.M.; Hamilton, R.I. Effect of inoculation position, timing, macrocondial concentration, and irrigation on resistance of maize to Fusarium graminearum infection through kernels. Can. J. Plant Pathol. 1996, 18, 279-285. [CrossRef]

38. Serrano, A.B.; Font, G.; Mañes, J.; Ferrer, E. Emerging Fusarium mycotoxins in organic and conventional pasta collected in Spain. Food Chem. Toxicol. 2013, 51, 259-266. [CrossRef] [PubMed]

39. Zinedine, A.; Meca, G.; Mañes, J.; Font, G. Further data on the occurrence of Fusarium emerging mycotoxins enniatins (A, A1, B, B1), fusaproliferin and beauvericin in raw cereals commercialized in Morocco. FoodControl 2011, 22, 1-5. [CrossRef]

40. Meca, G.; Zinedine, A.; Blesa, J.; Font, G.; Mañes, J. Further data on the presence of Fusarium emerging mycotoxins enniatins, fusaproliferin and beauvericin in cereals available on the Spanish markets. Food Chem. Toxicol. 2010, 48, 1412-1416. [CrossRef] [PubMed]

41. Mahnine, N.; Meca, G.; Elabidi, A.; Fekhaoui, M.; Saoiabi, A.; Font, G.; Mañes, J.; Zinedine, A. Further data on the levels of emerging Fusarium mycotoxins enniatins (A, A1, B, B1), beauvericin and fusaproliferin in breakfast and infant cereals from Morocco. Food Chem. 2011, 124, 481-485. [CrossRef]

42. Goertz, A.; Zuehlke, S.; Spiteller, M.; Steiner, U.; Dehne, H.W.; Waalwijk, C.; de Vries, I.; Oerke, E.C. Fusarium species and mycotoxin profiles on commercial maize hybrids in Germany. Eur. J. Plant Pathol. 2010, 128, 101-111. [CrossRef]

43. Uhlig, S.; Torp, M.; Jarp, J.; Parich, A.; Gutleb §, A.C.; Krska, R. Moniliformin in Norwegian grain. Food Addit. Contam. 2004, 21, 598-606. [CrossRef] [PubMed]

44. Chelkowski, J.; Ritieni, A.; Wisniewska, H.; Mulé, G.; Logrieco, A. Occurrence of toxic hexadepsipeptides in preharvest maize ear rot infected by Fusarium poae in Poland. J. Phytopathol. 2007, 155, 8-12. [CrossRef]

45. Stanciu, O.; Juan, C.; Miere, D.; Loghin, F.; Mañes, J. Occurrence and co-occurrence of Fusarium mycotoxins in wheat grains and wheat flour from Romania. Food Control 2017, 73, 147-155. [CrossRef]

46. Jurjević, Ž.; Solfrizzo, M.; Cvjetković, B.; De Girolamo, A.; Visconti, A. Occurrence of beauvericin in corn from Croatia. Food Technol. Biotech. 2002, 40, 91-94. 
47. Malachova, A.; Sulyok, M.; Beltran, E.; Berthiller, F.; Krska, R. Optimization and validation of a quantitative liquid chromatography-Tandem mass spectrometric method covering 295 bacterial and fungal metabolites including all regulated mycotoxins in four model food matrices. J. Chromatogr. A 2014, 1362, 145-156. [CrossRef] [PubMed]

48. Malachova, A.; Sulyok, M.; Beltrán, E.; Berthiller, F.; Krska, R. Multi-toxin determination in food - the power of "Dilute and Shoot" approaches in LC-MS-MS. LCGC Eur. 2015, 28, 542-555.

49. Stadler, D.; Sulyok, M.; Schuhmacher, R.; Berthiller, F.; Krska, R. The contribution to lot-to-lot variation to the measurement uncertainty of an LC-MS-based multi-mycotoxin assay. Anal. Bioanal. Chem. 2018, 410, 4409-4418. [CrossRef]

50. R Core Team. R: A Language and Environment for Statistical Computing; R Foundation for Statistical Computing: Vienna, Austria, 2013; ISBN 3-900051-07-0. Available online: http://www.R-project.org/ (accessed on 30 April 2019).

(C) 2019 by the authors. Licensee MDPI, Basel, Switzerland. This article is an open access article distributed under the terms and conditions of the Creative Commons Attribution (CC BY) license (http://creativecommons.org/licenses/by/4.0/). 